\title{
RIZODEGRADASI UNTUK MINIMALISASI BOD, COD, KANDUNGAN DERTERGEN DAN LEMAK LIMBAH CAIR RUMAH MAKAN
}

\author{
N. G. A. M. D. A. Suastuti ${ }^{1}{ }^{*}$, I. E. Suprihatin ${ }^{1}$, W. D. Sulihingtyas ${ }^{1}$ dan A. A .I .A. M. Laksmiwati ${ }^{1}$ \\ ${ }^{1}$ Fakultas Matematika dan Ilmu Pengetahuan Alam, Universitas Udayana, Bukit Jimbaran, Badung, \\ Bali \\ *E-mail: dwiadhisuastuti@unud.ac.id
}

\begin{abstract}
ABSTRAK
Penelitian ini bertujuan untuk mengetahui efektivitas dan kapasitas pengolahan limbah cair rumah makan dengan sistem rizodegradasi lahan basah yang menggunakan tanaman kangkungan (Ipomoea crassicaulis). Sistem ini dibuat dengan menanam stek tanaman kangkungan dalam bak ekosistem lahan basah. Air limbah ditentukan COD, BOD, konsentrasi lemak dan detergennya sebelum dan setelah pengolahan. Sebelum pengolahan, terlebih dahulu ditentukan $\mathrm{pH}$ kerja optimumnya. Limbah cair rumah makan diatur $\mathrm{pH}$ nya kemudian dialirkan ke dalam bak ekosistem lahan basah. Pengolahan air limbah dilakukan selama 6, 12, 18 dan 24 jam, dan pada setiap jangka waktu diambil sampel untuk diukur BOD, COD, konsentrasi detergen dan lemaknya. Hasil penelitian menunjukkan $\mathrm{pH}$ optimum dicapai pada range $6-8$. Nilai BOD, COD, konsentrasi lemak dan detergen dalam limbah sebelum diolah berturut-turut 246; 573,34; 128,0, dan 7,38 ppm, dengan $\mathrm{pH} 4,43$. Selama pengolahan terjadi penurunan konsentrasi polutan, dengan penurunan terbesar terjadi pada waktu pengolahan 24 jam, yaitu sebesar 44,95; 72,8; 36,5 dan 3,49 ppm untuk BOD, COD, konsentrasi lemak dan detergen. Efektivitas ekosistem lahan basah untuk menurunkan COD, BOD, lemak dan detergen berturut-turut sebesar 79,59\%, 74,75\%, 46,22\% dan 35,39\%. Kapasitas pengolahan ekosistem lahan basah untuk penurunan COD, BOD, lemak dan detergen berturut-turut sebesar 2,359; 1,108; 0,263 dan $0,016 \mathrm{ppm} / \mathrm{L}$ jam.
\end{abstract}

Kata kunci: rizodegradasi, lahan basah, limbah rumah makan, lemak, detergent

\begin{abstract}
This paper reports the investigation on the use of wet land technology to reduce the BOD, COD, fat, and detergent contents in restaurant waste using Ipomoea crassicaulis plant. The liquid waste was allowed to flow into the wet land containing the growing plants for 24 hours. The samples which was the original waste and those collected after $6,12,18$, and 24 hours of flowing were collected and measured for their BOD, COD, fat, and detergent contents. The result of BOD, COD, fat and detergent contens of theboriginal waste restaurant were of 246; $573.4 ; 128.0$, and $7.38 \mathrm{ppm}$, respectively with $\mathrm{pH}$ value of 4.43 . The results of the research revealed that the optimum decrease occured was at a $\mathrm{pH}$ range of 6-8. The results revealed that during the 24 hour treatment, the parameters measured of BOD, COD, fat and detergent contens decreased by 44.95; 72.8, 36.5; and 3.49 ppm, respectively. The effectiveness of the treatment in reducing the BOD, COD, fat, and detergent contents were of $79.59 \% ; 74.75 \%, 46.22 \%$ and $35.39 \%$. The treatment capacity of the wet land in reducing the pollution parameters were of $2.359 ; 1.108 ; 0.263$ and $0.016 \mathrm{ppm} / \mathrm{L} /$ hour, respectively
\end{abstract}

Keywords: detergent, fat, restaurant waster, hyzodegradation, wetland

\section{PENDAHULUAN}

Perkembangan rumah makan dewasa ini sangat pesat. Rumah makan menggunakan bahan baku seperti beras, sayur, daging, ikan, bumbu dan minyak yang diolah menjadi berbagai jenis makanan siap saji. Dalam proses pengolahannya digunakan minyak yang cukup banyak misalnya dalam menggoreng bahan maupun untuk menumis bumbu. Minyak yang digunakan untuk menggoreng tidak bisa digunakan secara terus menerus karena minyak ini sudah berwarna hitam dan mempengaruhi kenampakan dan cita rasa dari makanan yang diolah, sehingga harus dibuang. Dengan sendirinya kegiatan rumah makan menghasilkan limbah baik padat maupun cair. 
Limbah padat yang dihasilkan didomisasi oleh sisa makanan dan sisa sortasi sayuran, sedangkan limbah cair didominasi oleh minyak dan sabun hasil cucian peralatan makan. Limbah padat biasanya dimanfaatkan untuk bahan makanan ternak sedangkan limbah cair dibuang langsung ke perairan. Limbah cair yang mengandung lemak, bumbu, sisa makanan yang berukuran kecil yang terikut dalam pencucian serta sabun atau detergen yang digunakan dalam proses pencucian piring dan peralatan memasak, akan mencemari lingkungan kalau tidak diolah lebih dahulu sebelum dibuang (Zoraya dan Purwanti, 2015).

Kebanyakan rumah makan terutama rumah makan yang berukuran kecil tidak mempunyai sistem pengolahan limbah sehingga limbah terutama limbah cair dibuang langsung ke lingkungan. Limbah cair yang mengandung bahan minyak dan sabun ini akan berdampak buruk bagi ekosistem dan biota air dalam perairan yang dialiri oleh limbah tersebut.

Tidak tersedianya sistem pengolahan limbah yang murah dan praktis merupakan penyebab utama pengusaha rumah makan tidak mengolah limbah mereka sebelum dibuang ke lingkungan. Oleh karena itu sangat penting diperkenalkan sistem pengolahan limbah yang ekonomis, efektif, dan mudah dibuat. Proses pengolahan limbah biologis merupakan alternatif yang tepat untuk menjawab persoalan tersebut (Suprihatin, dkk., 2011; Suyasa, dkk., 2012; Dewi, dkk., 2016). Salah satu kelebihan pengolahan limbah biologis adalah adanya potensi pemanfaatan material alami yang tersedia melimpah maupun kemampuan tanaman air dalam menetralisir komponen-komponen tertentu di dalam perairan (Stowell, 2000 dalam Guntur, 2008). Proses biologis memanfaatkan organisme untuk mendegradasi zat kimia dalam limbah, baik organik maupun anorganik. Teknologinya dapat berupa trikling filter (Suprihatin, dkk., 2015; Agustina, dkk., 2016), lumpur aktif, lahan basah, dan lain sebagainya. Pemanfaatan ekosistem lahan basah telah banyak dilakukan di berbagai tempat guna mereduksi kandungan polutan air limbah dengan mengandalkan peranan ekosistem (Suyasa, dkk., 2007; Etsuko, K., 2007; Sandhika, dkk., 2012; Suprihatin, et.al, 2011 ; Suyasa, dkk., 2012; Suprihatin, dkk., 2015).
Artikel ini menyajikan penggunaan sistem lahan basah untuk mengolah limbah cair rumah makan untuk menurunkan kandungan detergen dan minyaknya.

\section{MATERI DAN METODE}

\section{Bahan}

Bahan-bahan yang diperlukan dalam penelitian ini adalah sampel air limbah rumah makan. Batu kerikil, pasir, dan bibit kangkungan (Ipomea crassicaulis) untuk lahan basah. Beberapa bahan kimia utama untuk pengukuran detergen dan minyak lemak, antara lain $\mathrm{NaOH}$, aquades, Natrium azida, $\mathrm{MnSO}_{4}$, amylum, $\mathrm{CHCl}_{3}, \mathrm{LAS}$, $\mathrm{Na}_{3} \mathrm{PO}_{4}, \mathrm{H}_{2} \mathrm{SO}_{4}, \mathrm{HCl}, \mathrm{HNO}_{3}, \mathrm{Hg}_{2} \mathrm{Cl}_{2}, \mathrm{KI}$, asam sitrat, $\mathrm{K}_{2} \mathrm{Cr}_{2} \mathrm{O}_{7}, \mathrm{Na}_{2} \mathrm{~S}_{2} \mathrm{O}_{3}, \mathrm{FeNH}_{4} \mathrm{SO}_{4}$, n-heksan, MTBE, $\mathrm{Na}_{2} \mathrm{SO}_{4}$.

\section{Paralatan}

Alat-alat yang diperlukan dalam penelitian ini antara lain : bak kaca untuk media tanaman, pipa dan saluran sampling port. Seperangkat alat refluks, buret, $\mathrm{pH}$ meter, statif, alat-alat gelas, kertas saring, timbangan analitik dan desikator.

\section{Cara Kerja \\ Penyediaan Tanaman Pada Ekosistem Lahan Basah}

Bibit (stek batang) kangkungan (Ipomea crassicaulis) ditanam di tanah yang dicampur pasir selama \pm 1 bulan. Konstruksi unit lahan basah terdiri dari sebuah tempat semaian ukuran kurang lebih $220 \mathrm{~cm} \times 120 \mathrm{~cm} \times 50 \mathrm{~cm}$ dilengkapi tabung pengambilan sampel. Bak perlakuan diisi batu koral setinggi $15 \mathrm{~cm}$, kemudian diatasnya campuran pasir dan sedikit tanah setinggi $30 \mathrm{~cm}$. Pada lapisan pasir ini ditanam kangkungan (Ipomea crassicaulis) yang sudah tumbuh, yang banyaknya disesuaikan dengan panjang dan lebar akar yang memungkinkan sebagian besar lapisan itu terisi oleh risosfir. Tanaman ini diadaptasikan selama \pm 2 minggu.

\section{Pemeriksaan Sampel Limbah Cair}

Karakteristik sampel air limbah ditentukan dengan mengukur $\mathrm{pH}$, suhu, BOD, COD, kandungan detergen dan lemaknya mengikuti prosedur standar (Clesceri, et.al., 1998). 


\section{Penentuan Kisaran pH Kerja}

Air limbah diatur pHnya kearah asam yaitu pada pH 6, 5 dan 4, dan kearah basa pada 8 , 9 dan 10. Air limbah dengan masing-masing $\mathrm{pH}$ kemudian dialirkan ke dalam bak pengolahan lahan basah. Dalam bak tersebut limbah diperlakukan selama 24 jam kemudian sampel diambil untuk diukur BOD dan COD nya. Digambarkan kurva konsentrasi masing-masing terhadap $\mathrm{pH}$ dan ditentukan kisaran $\mathrm{pH}$ efektif kerja sistem.

\section{Penentuan Efektivitas dan Kapasitas Pengolahan}

Air limbah diatur pHnya sesuai $\mathrm{pH}$ kerja (dalam hal ini dipakai pH 7), kemudian dialirkan kedalam bak ekosistem lahan basah. Dalam bak tersebut air limbah diperlakukan dengan merendamnya selama $6,12,18$, dan 24 jam. Pada setiap waktu yang ditentukan sampel diambil untuk diukur kandungan detergen serta lemaknya. Dari kurva konsentrasi terhadap waktu perendaman akan diperoleh kemampuan maksimal ekosistem buatan dalam menurunkan kadar pencemar air limbah. Efektivitas dan Kapasitas pengolahan ditentukan pada rentang waktu perendaman yang memberikan konsentrasi terendah.

\section{PEMBAHASAN}

\section{Karakteristik Limbah Rumah Makan.}

Hasil analisis limbah rumah makan disajikan dalam Tabel 1 berikut:

Tabel 1. Karateristik Limbah Rumah Makan

\begin{tabular}{clcc}
\hline No & Parameter & Satuan & $\begin{array}{c}\text { Hasil } \\
\text { Analisis }\end{array}$ \\
\hline 1. & pH & - & 4,43 \\
2. & BOD & Ppm & 246,6 \\
3. & COD & Ppm & 537,34 \\
4. & Lemak & Ppm & 128.0 \\
5. & Detergen & Ppm & 7,38 \\
\hline
\end{tabular}

Karakteristik limbah rumah makan ini telah melampaui baku mutu limbah domestik menurut peraturan Gubernur Bali no 16 tahun 2016. Bila limbah ini dibuang langsung ke perairan maka dapat menimbulkan pencemaran lingkungan.

\section{Kisaran pH Kerja}

Kisaran $\mathrm{pH}$ kerja ditentukan dengan mengatur $\mathrm{pH}$ limbah menjadi $6,5,4,8,9$ dan 10 mengolahnya dalam lahan basah selama 24 jam, kemudian mengukur COD dan BODnya. Hasilnya dapat dilihat pada Gambar 1.

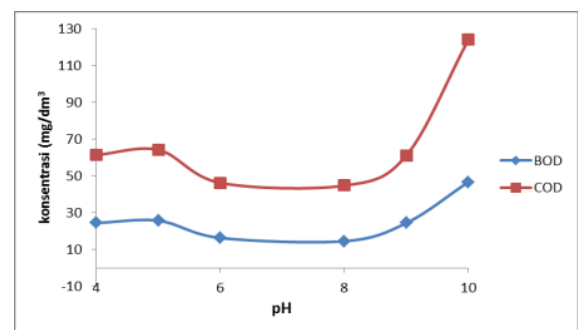

Gambar 1 Grafik Nilai BOD dan COD setelah 24 jam perlakuan pada berbagai $\mathrm{pH}$

Dari kurva pada Gambar 1 terlihat bahwa BOD dan COD terendah dicapai pada kisaran $\mathrm{pH}$ 6-8, sehingga kisaran $\mathrm{pH}$ kerja optimum adalah 6 8. Selanjutnya penentuan efektivitas dan kapasitas pengolahan dilakukan pada $\mathrm{pH}$ 7. Adapun nilai COD, BOD, kadar detergen dan lemak disajikan dalam Tabel 2.

\section{Efektivitas dan Kapasitas Pegolahan}

Hasil analisis BOD, COD, Kadar Lemak dan detergen air limbah selama waktu pengolahan disajikan pada Tabel 2.

Tabel 2 BOD, COD, kadar Lemak dan Detergen air limbah selama pengolahan

\begin{tabular}{ccccc}
\hline $\begin{array}{c}\text { Waktu } \\
\text { (jam) }\end{array}$ & $\begin{array}{c}\text { COD } \\
(\mathrm{mg} / \mathrm{L})\end{array}$ & $\begin{array}{c}\text { BOD } \\
(\mathrm{mg} / \mathrm{L})\end{array}$ & $\begin{array}{c}\text { Lemak } \\
(\mathrm{mg} / \mathrm{L})\end{array}$ & $\begin{array}{c}\text { Detergen } \\
(\mathrm{mg} / \mathrm{L})\end{array}$ \\
\hline 6 & 133,45 & 79,77 & 49,50 & 5,552 \\
12 & 109,19 & 69,33 & 40,40 & 5,291 \\
18 & 76,84 & 46,33 & 35,90 & 5,031 \\
24 & 72,79 & 44,95 & 36,50 & 4,227 \\
\hline
\end{tabular}


Efektivitas pengolahan limbah untuk mengetahui prosentase penurunan konsentrasi polutan oleh sistem pengolahan yang dipakai. Menurut Suyasa, dkk., (2012) dan Sandhika, dkk., (2012), secara matematis efektivitas pengolahan dapat dinyatakan sebagai berikut :

$$
\text { efektivitas }=\frac{A-B}{A} \times 100 \%
$$

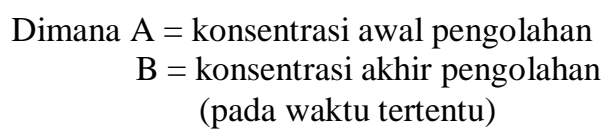

Menurut Suyasa, dkk., (2012) perhitungan kapasitas dinyatakan sebagai berikut :

Kakasitas $=\frac{(\mathrm{A}-\mathrm{B}) \mathrm{ppm}}{\mathrm{V} \mathrm{tR}}$

Dimana : $\mathrm{A}=$ konsentrasi awal pengolahan

$\mathrm{B}=$ konsentrasi akhir pengolahan

$\mathrm{V}=$ Volume pengolahan (liter)

$\mathrm{tR}=$ waktu tinggal (jam)

Dari hasil perhitungan menggunakan rumus diatas dapat ditentukan efektivitas dan kapasitas pengolahan untuk masing-masing parameter uji yang dilakukan dan disajikan pada Tabel 3, Gambar 2, dan Gambar 3.

Tabel 3 Efektivitas dan kapasitas pengolahan sistem lahan basah

\begin{tabular}{llcc}
\hline No & Parameter & $\begin{array}{c}\text { Efektivitas } \\
(\%)\end{array}$ & $\begin{array}{c}\text { Kapasitas } \\
\text { ppm/Ljam }\end{array}$ \\
\hline 1 & COD & 79,59 & 2,539 \\
2 & BOD & 74,75 & 1,816 \\
3 & Lemak & 46,22 & 0,263 \\
4 & Detergen & 35,39 & 0,016 \\
\hline
\end{tabular}

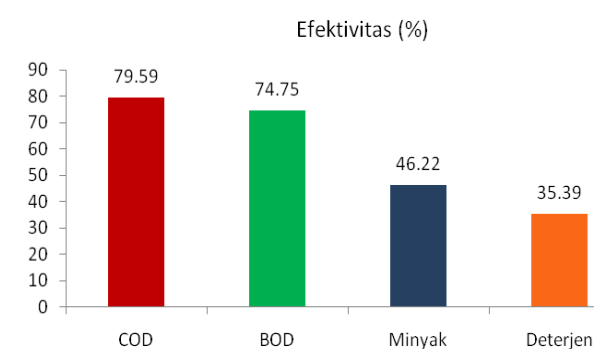

Gambar 2 Grafik batang efektivitas pengolahan

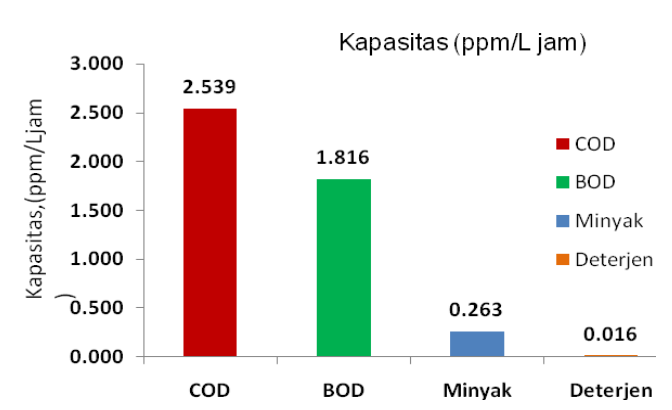

Gambar 3 Grafik batang kapasitas pengolahan

Dari Table 2 serta Gambar 2 dan 3, terlihat bahwa efektivitas dan kapasitas pengolahan oleh sistem terendah terjadi pada deterjen. Hal ini disebabkan oleh detergen yang digunakan sukar dirombak secara mikrobiologis selama pengolahan, sehingga sebagian besar detergen masih tertinggal dalam sistem. Keberadaan deterjen dalam perairan dapat mengakibatkan timbul buih yang menghalangi penetrasi oksigen ke dalam badan air, sehingga dapat mengganggu kelangsungan hidup organisma dalam perairan.

Terlihat juga bahwa sistem lahan basah ini memiliki kapasitas pengolahan BOD sebesar 2,359 $\mathrm{ppm} / \mathrm{L}$ jam yang artinya sistem pengolahan ini mampu menurunkan nilai BOD sebesar 2,359 ppm dalam 1 liter limbah setiap 1 jam pengolahan (Suyasa, dkk., 2012)

Mikroorganisme mempunyai peran yang sangat penting dalam pengolahan secara biologis, hal ini disebabkan oleh mikroorganisme memanfaatkan limbah sebagai sumber makanannya. Adanya berbagai senyawa seperti karbohidrat, lemak dan protein dalam limbah sangat diperlukan dalam metabolisme mikroorganisme. Senyawa-senyawa tersebut menjadi sumber energi bagi kehidupan mikroorganisme yang selanjutnya akan dirombak menjadi senyawa karbon sederhana dan air (Ginting, 2008). Hasil perombakan bahan organik yang terdapat dalam limbah cair oleh mikroorganisme akan dimanfaatkan oleh tumbuhan sebagai nutrient, sedangkan sistem perakaran tumbuhan air akan menghasilkan oksigen dan eksudat lain yang dapat digunakan sebagai oksidator dalam tahapan proses 
metabolism bagi kehidupan mikroorganisme (Dzantor, 2007).

\section{SIMPULAN}

Berdasarkan hasil penelitian dan pembahasan dapat ditarik simpulan sebagai berikut

1. $\mathrm{pH}$ kerja optimum pengolahan lahan basah diperoleh pada $\mathrm{pH} 6-8$

2. Efektivitas pengolahan dari sistem lahan basah menggunakan tanaman kangkungan untuk menurunkan konsentrasi COD, BOD, deterjen dan lemak adalah 79,59\%, 74,75\%, 46,22\% dan $35,39 \%$.

3. Kapasitas pengolahan tertinggi dicapai pada penurunan COD sebesar $2,539 \mathrm{ppm} / \mathrm{L}$ jam.

\section{Ucapan terimakasih}

Penulis sangat bersyukur telah didanai oleh melalui Hibah Unggulan Program Studi dengan nomor kontrak 2751/UN14.1.28/LT/2016

\section{DAFTAR PUSTAKA}

Agustina, A., Suprihatin, I.E., Sibarani, J., 2016. Pengaruh biofilm terhadap efektivitas penurunan BOD, COD, TSS, minyak dan lemak dari limbah pengolahan ikan menggunakan trickling filter, Cakra Kimia, 4 (2):137-145.

Clesceri, L.S., Greenberg, A.E., and Eaton, A.D.(editor), 1998, Standard Methods for the Examination of Water and Waste Water, $20^{\text {th }}$ edition, APHA., Washington DC.

Dewi, I G.A.K.S.P., Suarya, P., Suprihatin, I.E., Dwijani,W., 2016, Penurunan BOD, COD, dan zat warna limbah pencelupan dengan fitoekstraksi menggunakan kiambang (Salvinia natans), Bumi Lestari, 16(1):1115.

Dzantor , E. K., 2007. Phytoremediation: the state of rhizosphere 'engineering' for accelerated rhizodegradation of xenobiotic contaminants"., Journal of Chemical Technology and Biotechnology, 82(3): 228-232.
Etsuko, K., 2007, Effect of Rhizodegradation in Diesel-contaminated Soil under Different Soil Conditions., Plant Prod Sci., 10 (1): 105-111.

Ginting Perdana, 2008. Sistem Pengelolaan Lingkungan dan Limbah Industri. Yrama Widya. Bandung.

Peraturan Gubernur Bali No 16 Tahun 2016. Tentang Baku Mutu Lingkungan Hidup dan Kreteria Baku Kerusakan Lingkungan Hidup. Lampiran II.

Sandhika, I.M.G., Suprihatin, I.E., dan Suyasa, I.W.B. 2012. Pengolahan limbah pencucian rumput laut dengan ekosistem buatan, Jurnal Kimia, 6 (2): 148-154.

Suprihatin, I.E., Sulihingtyas, W.D., Suyasa, IW.B., 2011, Rhyzodegradation of oil waste, proceeding on the $3^{\text {rd }}$ International Conference on Bioscinces and Biotechnology, Bali, September 2011.

Suprihatin, I.E., , Suyasa, IW.B., Laksmiwati, AAIAM, 2015, Penurunan kandungan amonia limbah cair dengan kombinasi trikling filter dan lahan basah, Proseding Senastek, 29-30 Oktober 2015, Denpasar, 1998-2002.

Suyasa, I.W B. dan Dwijani, W., 2007, Kemampuan Sistem Saringan PasirTanaman Menurunkan Nilai BOD dan ammonia, nitrit, dan nitrat Air Tercemar Limbah Pencelupan, Ecotrophic., 2 (1): 17.

Suyasa, I.W.B., Suprihatin, I.E., dan Rafika, G.A., 2012. Pengolahan Limbah Pembangkit Listrik dengan saringan Pasir-tanaman, Jurnal Kimia, 6(1): 62-71.

Guntur, Y. 2008. Bioremidiasi Limbah Rumah Tangga dengan Sistem Simulasi Tanaman Air, Jurnal Bumi Lestari, 8(2): 136-144.

Zoraya, Z.L. dan Purwanti, I.F., 2015. Pengolahan Limbah Rumah Tangga dengan Proses Biofilter Aerobik. Jurnal Teknik ITS. 4(1): 35-39. 